\title{
Learning from each other: Expanding and deepening international research on shadow education
}

\section{JÁNOS GORDON GYŐRI ${ }^{1 *}$ (1) and MARK BRAY ${ }^{2,3}$ (1)}

\author{
${ }^{1}$ Faculty of Education and Psychology, Institute for Intercultural Psychology and Education, Eötvös \\ Loránd University Budapest, Hungary \\ ${ }^{2}$ Centre for Research in Supplementary Tutoring (CIRIST), Faculty of Education, East China Normal \\ University, Shanghai, China \\ ${ }^{3}$ The University of Hong Kong, Pok Fu Lam, Hong Kong
}

\section{RESEARCH ARTICLE}

\section{ABSTRACT}

Research on private supplementary tutoring, widely known as shadow education, has a long history but only gathered intensity during the present century. This research has shown much diversity in the scale and nature of shadow education, but further mapping and analysis is needed to reduce gaps in understanding and to keep up with changes. The collection of articles in this special issue of the journal presents insights from parts of Africa, Asia and Europe; and this introductory essay juxtaposes these insights with Hungarian research. The domain of shadow education has many tensions, with both positive and negative implications for individuals, families, the field of education, and societies as a whole. International research helps with understanding these tensions, and in due course with appropriate action to address them. In the process, much can be learned from counterparts in different systems, countries and cultures, not only about the nature and impact of shadow education but also about methodological approaches to research.

\section{KEYWORDS}

private tutoring, shadow education, comparative education, research methods

\footnotetext{
*Corresponding author. E-mail: gyori.janos@ppk.elte.hu
} 
This special issue of the Hungarian Educational Research Journal (HERJ) focuses on the phenomenon of private supplementary tutoring, which in academic circles is widely known as shadow education. The metaphor is used because much tutoring content mimics that in regular schooling: as the curriculum changes in the schools, so it changes in the shadow (Aurini, Davies, \& Dierkes, 2013; Bray, 1999; Buchmann, Condron, \& Rosigno, 2010). Researchers commonly recognise that for various reasons the metaphor is imperfect (see e.g. Bray, Kwo, \& Jokić, 2015; Grodsky, 2010), but it is nevertheless evocative and useful.

Shadow education is taken here to mean paid tutoring in academic subjects beyond the provision of schooling. This tutoring may be conducted one-to-one, in small groups, or in large classes. While traditionally such tutoring has been and remains delivered face to face, increasingly it is delivered over the internet (see e.g. Takashiro, 2018). The shift to internet provision was accelerated by the Covid-19 pandemic that hit the world in 2020 and closed schools for extended durations.

International research on this theme has expanded greatly in recent decades (Gordon Györi, 2020a; Zhang \& Bray, 2020), but much more work is needed both to reduce gaps in knowledge and to keep up with constant changes. In this process, as of course in all other domains, researchers can learn a lot from each other both within and across national boundaries. We are glad in this collection of papers to add to the research literature.

\section{CONTEXTS AND CONTRIBUTIONS}

Since the HERJ is a Hungarian publication, we commence by informing the international audience about some research in Hungary. We then turn to the contributions of the papers in this issue of the HERJ, to consider ways in which they may be juxtaposed with both Hungarian and other research.

\section{Some Hungarian perspectives}

Shadow education in Hungary has a longer history as a significant phenomenon than is widely recognised. In 1988, for example, Inkei, Koncz and Pőcze (p. 60) described tutoring as type of 'purchaseable learning' that was utilised mostly by the children of 'leaders and intellectuals' in the cities. ${ }^{1}$ They cited a 1982 study indicating that children of such families spent almost one third of their total learning time in the activity, highlighting the impact on family budgets. Presumably such tutoring existed long before 1982, even though it may not have attracted the attention of the research community.

Especially significant about the above-mentioned study is that it was conducted during the Soviet-dominated Communist era. With the collapse of Soviet Communism in 1991 and the shift to the market economy in all parts of the former Soviet bloc, shadow education developed further. It was still not a focus of significant research in Hungary, though authors elsewhere in Eastern Europe focused on themes that likely had parallels (see e.g. Długosz, 2012; Jokić, Soldo, \& Ristić Dedić, 2013; Kubánová, 2006; Št’astný, 2016).

\footnotetext{
${ }^{1}$ 'Leaders and intellectuals' was an official statistical category at that time.
} 
More recently (and arguably belatedly), the topic has received focus in a special issue of the Hungarian-language journal Educatio (Bíró, 2020; Gordon Győri, 2020b; Imre, 2020; Polónyi, 2020; Setényi, 2020; Szemerszki, 2020). In his introductory article to that special issue, Gordon Győri (2020b) defined shadow education in its narrowest sense, i.e. out-of-school, for-fee education activities in the most important examination subjects. These subjects are mathematics, foreign language (especially English), and reading literacy (mother tongue and literature). After this definition he introduced some theoretical debates and important research directions. He then offered a new approach to reach a more sophisticated understanding of at least some dimensions of shadow education and related phenomena via 'educational behavioural science'. This domain, like behavioural economics and other behavioural sciences, integrates psychological, sociological, economic, behavioural and educational perspectives. It can assist analysts of shadow education to understand the developing and increasingly penetrating role of this form of learning and teaching activity. Gordon Györi also argued for a new type of training for so-called educational-space specialists who can help families needing this service to find the best combinations of formal, shadow and other educational possibilities.

Other papers in the Educatio special issue emphasised specifically-Hungarian features. For example Polónyi (2020) commenced with the shadow economy rather than shadow education, defining the shadow economy "in its peculiar Hungarian version". Then, in an echo of Inkei, Koncz, and Pöcze (1988), he examined shadow education in relation to the shadow economy. He followed a deficiency approach, stating that shadow education was a market response to the inability of mainstream education to address many students' individual needs and abilities.

Next in the special issue, Szemerszki (2020) reviewed data from the Hungarian National Assessment of Basic Competences. She showed that as student age progressed, the emphasis on in-school free supplementary and extra-curricular activities (remedial education by teachers of the school, arts, clubs, sports, etc.) shifted towards out-of-school activities with academic emphases. The corollary was a decline in the proportions of arts, clubs and sports. Szemerszki also found instructive social differences in the shadow education sector between foreign languages (especially English) and mathematics. Most clients for foreign languages were from relatively privileged families, while those for extra (and mostly remedial rather than enrichment) mathematics tended to come from less privileged social groups. This finding reflected the emphasis among privileged families in preparing for the globalised, international arena of education, while lower-income parents focused on preventing early drop-out (or push-out) from the national education system.

Concerning the remaining papers in the collection, Imre focused on primary school students' use of three different learning arenas: classroom, in-school extracurricular, and out-of-school extracurricular. For over half of the primary school students that she investigated, the three learning arenas were not mutually exclusive and were apparently a permanent feature. However, opportunities for student participation in the three learning environments could compete with each other as well as complement.

Bíró then focused on the identities and modes of operation of tutors as reflected in online advertisements. She located advertisements for 453 tutors in English and 118 tutors in mathematics. Over half of the service providers were certified teachers, and in their advertisements they used this training as the most important factor to bolster their legitimacy in the shadow education sector. Average prices for one-hour English lessons were 4,000 forints (US\$12), but prices varied e.g. according to whether the teacher used to live in an English-speaking environment, the lessons were run on one-to-one basis, and the tutor travelled/commuted to the student or vice versa. Bíró 
also found that female tutors charged less than males, with a particularly wide gap in the domain of information technology. This gender bias in the Hungarian marketplace deserves attention by scholars who may see if it is evident elsewhere. Among the questions are why females charged less, and in that respect whether it was a self-imposed gender bias.

Finally Setényi, like Imre, examined relationships between nonformal education and its connection with traditional schooling. He highlighted the shift from symbiosis to disruption, noting particularly the impact of technological innovations. He expressed a hope that mentorsupported problem-based individual or/and team learning would be the most influential model for learning in the future.

\section{Perspectives in the present collection}

The first paper in this HERJ collection focuses on China, which remains a Communist country albeit with a markedly different orientation from that of previous decades. Feng notes that from the foundation of the People's Republic of China in 1949 until after the death of Mao Tse-tung in 1976, privateness was removed from the education sector. Teachers, Feng records, were supposed to devote unreserved efforts to their students without unethical fee-charging, and Chinese scholars criticised the roles in the Soviet Union of private tutoring classes that secured the reproduction desires of the privileged elite. In 1978, however, China commenced a shift towards a market economy that gathered speed in the 1980s and accelerated further in the 1990s and after. Fee-charging shadow education emerged within this environment, and changed shape with the acceleration of marketisation. The country remained under Communist leadership and control, but the authorities tolerated expanded provision of private tutoring for pragmatic reasons. Initially teachers sought to supplement their salaries, and schools used tutoring to support their institutional budgets. Then during the 1990s commercial entrepreneurs began to offer more institutionalised models through tutorial centres operating in parallel to schools.

Following the turn of the century, Feng observes, the tutorial sector became more industrialised with inputs from large-scale investors. Prominent companies established hundreds of branches around the country, and the exponential market growth attracted the attention of international investors. By 2019, over 20 companies were listed on the stock exchanges of Mainland China, Hong Kong and the USA. Small operators remained numerically dominant, but the capitalisation brought significant changes to the industry and transcended the boundaries of conventional tutoring by providing online modes and diversified curricula. At the same time, the Chinese authorities became increasingly concerned not only about social inequalities but also about study burdens on students and about corruption in relationships when public teachers and schools also provided tutoring. The authorities devised regulations to address these issues and to constrain both demand and supply (Zhang, 2019), but it remains the case, as observed by Feng, that "private supplementary tutoring has become a major component of students' educational experiences".

The next article, by Peng, in some respects elaborates with a focus on social inequalities and shadow education in China. The country faces major issues of rural/urban imbalances that overlap with social imbalances (Zhang \& Bray, 2021). Between 1978 and 2018, the urban population expanded from $17.9 \%$ of the total to $59.6 \%$ (China, National Bureau of Statistics, 2019). Migration of adults, usually for work in the cities, created the problem of 'left-behind children' in the care of grandparents and others. Peng examines the phenomenon with the lens 
of 'concerted cultivation' initially employed by Lareau (2011) in the USA and echoed in other Western societies (Carolan, 2016; Irwin \& Elly, 2011; Siraj-Blatchford, 2010). His paper brings a Chinese flavour with data from children in a Sichuan community whose parents had migrated in most cases to Tibet as manual workers.

Elaborating, Peng shows ways in which parents used shadow education for their left-behind children. Nine $(34.6 \%)$ of the 26 primary school children that he interviewed had received shadow education because their parents saw it as a meaningful way to engage with educational processes and support their children's development. Even then, these parents commonly faced dis-alignment between what they hoped to do in terms of parenting logics and could do in terms of parenting practices. The remarks about the circumstances of particular students and their families highlighted the challenges of 'mixing zones' in the blurred boundaries of concerted cultivation and what Lareau (2011) had called 'natural growth', i.e. care within the more restricted boundaries of providing safety and necessities. Through such micro-level analysis, Peng draws out important themes for the wider picture and the complexities within it.

The following paper in the collection is from a former-Communist state, Kazakhstan. During the Soviet era, Kazakhstan was in many respects part of the collective USSR with restricted individual identity; but since Independence in 1991, Kazakhstan has forged its own route much assisted by economic revenues from oil and gas. Although shadow education received little attention in the immediate post-Independence era (though see Kalikova \& Zhanar, 2009), it was certainly a significant and growing phenomenon. Hajar and Abenova expand contemporary understanding of shadow education in Kazakhstan with their focus on engineering students' strategies for securing admission to a highly-selective university. Among the surveyed respondents, $59.7 \%$ had received private tutoring, with most describing it as an enrichment strategy to help obtain high examination scores. The authors highlight social inequalities based on wealth, and marked urban/rural disparities with only $5.6 \%$ of the total sample coming from rural areas. Among the ironies is that investments in tutoring during the school years led to state grants for the university years. Students whose families had not invested in tutoring were more likely to have access only to lower-tier universities in which fees were higher.

Although many authors have emphasised the importance of competition related to shadow education since the early writings (e.g. Marimuthu et al., 1991; Stevenson \& Baker, 1992) few focused attempts have been made to examine this or any closely related issue in terms of the experiences and thoughts of students involved in shadow education (though see Yung, 2015, 2019). To reduce this gap in the research, in their qualitative data collection Fülöp and Gordon Győri asked 356 Japanese senior high school and university students about their experiences and opinions. Compared to their Hungarian peers in a similar study (Fülöp \& Gordon Győri, 2021), the Japanese students stressed the beneficial functions and aspects of shadow education and competition, and expressed much less concern about possible negative aspects on equity and justice in education and society.

Finally, Bray's paper returns to the macro-level with insights from four countries. Like Feng, he takes a historical approach. The paper compares government (non-)policies on the provision of shadow education by serving teachers in public schools, and shows ways in which patterns have evolved. Bray commences with government discomfort about teachers providing private tutoring, in part because governments are mindful that such teachers may devote less effort to their official duties. Governments are especially concerned when teachers tutor the students for whom they are already responsible in schools, because such teachers may be tempted 
deliberately to reduce content in their official lessons in order to promote demand for tutoring. These teachers may also discriminate against non-tutored students during their school lessons. Bray notes that these issues arise in countries as diverse as Cambodia, Egypt, France and Zimbabwe, but the paper focuses on the Republic of Korea, Mauritius, Kenya, and England.

The core message of Bray's paper is that governments that wish to discourage or even prohibit regular teachers from providing private supplementary tutoring have to swim against the tide of other forces. Parents look after their own self-interests, including by soliciting extra support from teachers if allowed to do so; and teachers, supported by their unions, may feel that they have the right to provide the service. Governments are in a particularly weak position when they do not pay teachers at a level perceived to be adequate for the teachers' family needs and social status. The Korean government has succeeded in phasing out the practice, and in this respect has a parallel with China. In both countries, it has been possible because strong economies permit adequate salaries and because government machinery can monitor and enforce regulations. The authorities in Mauritius and Kenya have less capacity; and in England the government has have been ignoring the phenomenon rather than grappling with it.

\section{LEARNING FROM EACH OTHER}

The above remarks focus chiefly on the pair of collections in the Hungarian-language journal Educatio and in this edition of the HERJ, and already show many ways in which researchers can learn from each other. Some links have also been made to the broader literature, and deserve elaboration.

\section{Some core messages}

Beginning with China, the industrialisation of shadow education, which has also been evident elsewhere (see e.g. Bukowski, 2017; Christensen, Grønbek, \& Bækdahl, 2021; Dierkes, 2013), shows the capacity for the sector to innovate and compete with schooling. At one end of the spectrum of providers are university students, retirees and others who work informally within their local communities, and at the other end are large national and even multinational companies quoted on stock exchanges. This would not have been envisaged in the Hungary of the 1980s presented by Inkei et al. (1988), or by the Chinese teachers and schools earning informal revenues during the same era. Equally it is still overlooked by policy-makers in parts of the world where shadow education does not currently have much visibility but it is likely to grow. This is the case in francophone Africa, for example, where policy-makers would be wise to take issues seriously precisely because shadow education is not yet deeply engrained in the cultures and is therefore still relatively amenable to steering (see e.g. Bray, 2021, pp. 66-74).

At the same time, many parents and even some policy-makers welcome shadow education in its diverse forms, feeling that it provides choice alongside relatively standardised systems of public schooling. Most forms of shadow education are tailored to meet the needs of the clients, and the sector has economic as well as educational significance. At the loose end of the scale, shadow education delivered by university students provides extra pocket money to subsidise living costs, and at the industrialised end of the scale the sector generates employment not only for the tutors themselves but also for ancillary services in supply of books, computers, etc. 
Shadow education of increasing size and importance has also played a role in a whole range of other innovative businesses, most notably different versions of online education.

However, while at least some benefits and advances have been evident, so also have been many problems, such as educational injustice and inequity. Shadow education has become one of the most important avenues for families and social groups who are already in better educational and social positions to gain even more advantages over others, thus undermining fundamental principles of justice and fairness. Shadow education thus has many critics, and many politicians, government officials, educationists and even lay people want to regulate shadow education in some way. However, this has constraints because shadow education satisfies a very important societal need that cannot be suppressed or changed by just a few provisions. Some politicians have attempted to ban shadow education in their countries, but the measure has never been straightforward or fully successful (Bray, 2021; Bray \& Kwo, 2014). Shadow education providers are usually able to evade bans and even some forms of regulation because families desire continued access to the services in the competitive societies.

The collection of articles, in conjunction with much related literature, also shows that the world of education is in the process of transformation of perhaps comparable significance to the emergence of national education systems in the $19^{\text {th }}$ and $20^{\text {th }}$ centuries. A core feature of this transformation is the growing space and importance of out-of-school learning and teaching alongside formal schooling. At the same time, competition is a fundamental feature of shadow education, especially because it is a marketized service, and makes shadow education almost blind to matters of educational injustice and social inequality.

Yet while much research to date has shed light on the economic and social aspects of competition in and through shadow education, Fülöp and Gordon Györi show that not only researchers and scholars but also many learners are aware of these issues. They experience and think about this challenging side of shadow education. Yet students are also mindful of the motivational aspects of shadow education, its function in knowledge-building, and its improving function in self-development. In this respect, these generations of students receiving shadow education are socialised in an educational activity which is a double-faced phenomenon. Nevertheless, this picture is not uniform since it is embedded in cultural patterns. Elsewhere, Fülöp and Gordon Györi (2020) show that Hungarian students tend to be sensitive towards the social and educational inequalities inherent in shadow education, but that Japanese students concentrate strongly on its motivational and developmental aspects.

\section{Methods and approaches}

The methodological diversity of the shadow education studies in this HERJ collection is also noteworthy. To some extent, of course, the methods are taken from the general toolbox that can be employed for more or less any domain of educational studies. As noted by Bray et al. (2015), however, research on shadow education does require some distinctive emphases arising in part from the fact that it is mostly a shadowy topic without statistics collected by Ministries of Education and comparable bodies.

Concerning the papers in this collection, for his historical analysis of shadow education in China, Feng drew on existing literature and openly available data sources. By contrast, Peng used qualitative data collection methods, carrying out semi-structured interviews. Hajar and Abenova used mixed methods to collect data from their first-year undergraduate participants: first, 
quantitative data were collected through a close-ended questionnaire, and later qualitative data were collected through interviewing. Also with a qualitative orientation, but carefully structured, Fülöp and Gordon Győri distributed an open-ended questionnaire among their Japanese participants. Finally, Bray's paper drew on existing literature to construct the broad picture and lessons from study of four countries.

This striking variety of methods underlines the extent to which shadow education is a multifaceted phenomenon, requiring multiple approaches for comprehensive understanding. Even then, much remains to be done. Research on shadow education is still in its infancy, with many underexplored dimensions (Zhang \& Bray, 2020). Readers who look around and browse the literature can find many other approaches for research on shadow education. Clearly, no individual or group has all-encompassing opportunities and knowledge to explore and understand this complex phenomenon: we all need to rely on each other to be able to unfold, know and understand shadow education in its complex manifestations and impacts.

\section{CONCLUSION}

While these papers are just a small addition to the expanding field, they help to push the boundaries. The remarks in England by founder of the Sutton Trust (quoted in Weale, 2018) are pertinent across the globe. "Tutoring is huge", he said; "it's getting bigger and it's not going away". The scale of tutoring varies across and within countries, as do the formats, curricula and other features. These variations are themselves of great interest, especially to scholars of comparative education.

With such matters in mind, we are glad to present this collection of papers to both the Hungarian and international audiences. Shadow education, like the body that it mimics, is multifaceted and needs exploration from multiple perspectives. At the same time, shadow education has become a phenomenon in its own right - not just mimicking mainstream schooling. Further, in some respects it is even more dynamic than mainstream schooling, in part because it is less constrained by bureaucracies and traditions. As such, we look forward to dialogue for further development of research in this field.

\section{REFERENCES}

Aurini, J., Davies, S., \& Dierkes, J. (Eds.), (2013). Out of the shadows: The global intensification of supplementary education. Bingley: Emerald.

Bíró, Zs.H. (2020). Az árnyékoktatásról internetes magánoktatói hirdetések tükrében [On shadow education in the light of online private tutor ads]. Educatio, 29(2), 243-260. [in Hungarian].

Bray, M. (1999). The shadow education system: Private tutoring and its implications for planners. Fundamentals of Educational Planning 61, Paris: UNESCO International Institute for Educational Planning (IIEP).

Bray, M. (2021). Shadow education in Africa: Private supplementary tutoring and its policy implications. Hong Kong: Comparative Education Research Centre, The University of Hong Kong. 
Bray, M., \& Kwo, O. (2014). Regulating private tutoring for public good: Policy options for supplementary education in Asia. Bangkok: UNESCO and Hong Kong: Comparative Education Research Centre, The University of Hong Kong.

Bray, M., Kwo, O., \& Jokić, B. (2015). Introduction. In M. Bray, O. Kwo, \& B. Jokić, (Eds.), Researching private supplementary tutoring: Methodological lessons from diverse cultures (pp. 3-19). Hong Kong: Comparative Education Research Centre, The University of Hong Kong, and Dordrecht: Springer.

Buchmann, C., Condron, D. J., \& Roscigno, V. J. (2010). Shadow education, American style: Test preparation, the SAT and college enrollment. Social Forces, 89(2), 435-462.

Bukowski, P. (2017). Shadow education within the European Union from the perspective of investment in education. European Expert Network on Economics of Education (EENEE). http://www.eenee.de/ eeneeHome/EENEE/Ad-Hoc-Questions.html.

Carolan, B. V. (2016). Unequal academic achievement in high school: The mediating roles of concerted cultivation and close friends. British Journal of Sociology of Education, 37(7), 1034-1055.

China, National Bureau of Statistics (2019). China statistical yearbook. Beijing: National Bureau of Statistics. http://www.stats.gov.cn/tjsj/ndsj/2019/indexeh.htm.

Christensen, S., Grønbek, T., \& Bækdahl, F. (2021). The private tutoring industry in Denmark: Market making and modes of moral justification. ECNU Review of Education [East China Normal University], 4. https://doi.org/10.1177/2096531120960742.

Dierkes, J. (2013). The insecurity industry: Supplementary education in Japan. In J. Aurini, S. Davies, \& J. Dierkes (Eds.), Out of the shadows: The global intensification of supplementary education (pp. 3-21). Bingley: Emerald.

Długosz, P. (2012). Korepetycje maturzystów pogranicza w latach 2008-2011 [Private lessons and the influence of the matura examination 2008-2011]. Kultura i Edukacja, 2(88), 88-106. [in Polish].

Fülöp, M., \& Gordon Győri, J. (2020). Árnyékoktatás és verseny: magyar középiskolások és egyetemisták nézetei az ányékoktatás és a verseny kapcsolatáról [Shadow education and competition: Hungarian high school and university students' views on the relationship between shadow education and competition]. Magyar Pedagógia (in press). [in Hungarian].

Gordon Győri, J. (2020a). Shadow education - opportunity for development. European Journal of Education, 55(3), 305-310.

Gordon Győri, J. (2020b). Árnyékoktatás: Alapfogalmak, kutatás, lehetőségek [Shadow education: Basic concepts, research, opportunities]. Educatio, 29(2), 171-187. [in Hungarian].

Grodsky, E. (2010). Learning in the shadows and in the light of day: A commentary on shadow education, education, American style: Test preparation, the SAT and college enrollment. Social Forces, 89(2), 475481.

Imre, A. (2020). Tanulás félárnyékban - tanórai, tanórán kívüli és iskolán kívüli tanulás az általános iskolákban [Learning in half shadow: Learning in classroom, extracurricular and out-of-school environments in primary schools]. Educatio, 29(2), 222-242. [in Hungarian].

Inkei, P., Koncz, G., \& Pöcze, G. (1988). The diversification of the educational field in Hungary. Paris: UNESCO International Institute for Educational Planning (IIEP).

Irwin, S., \& Elley, S. (2011). Concerted cultivation? Parenting values, education and class diversity. Sociology, 45(3), 480-495.

Jokić, B., Soldo, A., \& Ristić Dedić, Z. (2013): Private tutoring and social equity in Croatia and Bosnia \& Herzegovina: A comparative qualitative study. In M. Bray, A. E. Mazawi \& R. G. Sultana (Eds.), Private tutoring across the Mediterranean: Power dynamics and implications for learning and equity (pp. 1127). Rotterdam: Sense. 
Kalikova, S., \& Zhanar, R. (2009). Private tutoring in Kazakhstan. In I. Silova (Ed.), Private supplementary tutoring in Central Asia: New opportunities and burdens (pp. 93-118). Paris: UNESCO International Institute for Educational Planning (IIEP).

Kubánová, M. (2006). Slovakia. In I. Silova, V. Būdienè, \& M. Bray (Eds.), Education in a hidden marketplace: Monitoring of private tutoring (pp. 279-303). New York: Open Society Institute.

Lareau, A. (2011). Unequal childhoods: Class, race and family life ( $2^{\text {nd }}$ ed.). Berkeley, CA: The University of California Press.

Marimuthu, T., Singh, J. S., Ahmad, K., Lim, H. K., Mukherjee, H., Osman, S., et al. (1991). Extra-school instruction, social equity and educational quality [in Malaysia]. Singapore: International Development Research Centre.

Polónyi, I. (2020). Az árnyékoktatás oktatásgazdasági közelítésben [Shadow education in the educational economy approach]. Educatio, 29(2), 188-204. [in Hungarian].

Setényi, J. (2020). Az ,árnyékoktatás" metaforájától a tanulási rendszerekig [From "shadow education” to learning systems]. Educatio, 29(2), 261-278. [in Hungarian].

Siraj-Blatchford, I. (2010). Learning in the home and at school: How working class children 'succeed against the odds'. British Educational Research Journal, 36(3), 463-482.

Št'astný, V. (2016). Private supplementary tutoring in the Czech Republic. European Education, 48(1), 122.

Stevenson, D. L., \& Baker, D. P. (1992). Shadow education and allocation in formal schooling: Transition to university in Japan. American Journal of Sociology, 97(6), 1639-1657.

Szemerszki, M. (2020). Különórák az iskolában és iskolán kívül [Extra-curricular lessons at school and outof-school]. Educatio, 29(2), 205-221. [in Hungarian].

Takashiro, N. (2018). Technology use and middle school students' participation in shadow education in Japan. International Psychology Bulletin, 27(4), 14-21.

Weale, S. (2018). An education arms race': Inside the ultra-competitive world of private tutoring. The Guardian, 5 December. https://www.theguardian.com/education/2018/dec/05/an-education-arms-raceinside-the-ultra-competitive-world-of-private-tutoring.

Yung, K. W. H. (2015). Learning English in the shadows: Understanding Chinese learners' experiences of private tutoring. TESOL Quarterly, 49(4), 707-732. https://doi.org/10.1002/tesq.193.

Yung, K. W. H. (2019). Exploring the L2 selves of senior secondary students in English private tutoring in Hong Kong. System, 80, 120-133. https://doi.org/10.1016/j.system.2018.11.003.

Zhang, W. (2019). Regulating private tutoring in China: Uniform policies, diverse responses. ECNU Review of Education [East China Normal University], 2(1), 25-43.

Zhang, W., \& Bray, M. (2020). Comparative research on shadow education: Achievements, challenges, and the agenda ahead. European Journal of Education, 55(3), 322-341.

Zhang, W., \& Bray, M. (2021). A changing environment of urban education: Historical and spatial analysis of private supplementary tutoring in China. Environment and Urbanization, 33(1), 43-62.

Open Access. This is an open-access article distributed under the terms of the Creative Commons Attribution 4.0 International License (https://creativecommons.org/licenses/by/4.0/), which permits unrestricted use, distribution, and reproduction in any medium, provided the original author and source are credited, a link to the CC License is provided, and changes - if any - are indicated. (SID_1) 